\title{
The Challenge OF "LOW EMPloyment ECONOMIC GROWTH" IN SOUTH AFRICA: 1994 -2008
}

\author{
Darma Mahadea and Richard Simson \\ School of Economics and Finance, University of KwaZulu-Natal
}

Accepted September 2010

\begin{abstract}
Although the economy has registered positive economic growth over the past 15 years since the demise of apartheid, the formal sector in South Africa has been unable to provide adequate employment for labour. Against a background of the recent almost global recessionary climate, this lack of employment is a serious problem. While government has responded with many initiatives to deal with employment creation, unemployment rates in South Africa remain high. In this paper the problem of low employment economic growth performance is initially examined for the period 1994 -2008 by drawing on the Harrod-Domar model and then over a longer time period by using regression analysis. The paper uses a parsimonious regression model to highlight the probable links between changes in economic growth and changes in employment. The growth elasticity of employment over the 1994-2008 period is low and over a longer time horizon the marginal growth employment effect is weak.
\end{abstract}

Key words: Growth, employment, jobless growth, entrepreneurship

JEL O55, O17, J21

\section{1}

\section{Introduction}

South Africa registered an average growth rate of 3 per cent for the period 1994-2003, 5 per cent from 2004 to 2007, and 2.8 per cent in 2008 (SARB, 2009). Despite these growth rates, employment has not increased significantly. Employment increased by 1.8 million from 2004 to 2007 (du Toit \& van Tonder, 2009), and the number of employed people rose to 9.4 million in the third quarter of 2008, but as many as 366000 formal sector jobs were lost in the first three quarters of 2009 (SARB, 2009). It sounded encouraging when the President announced in his State of Nation address in February 2010, that 480000 jobs were created, but these seem to be mainly short-term, non sustainable employment of a public works nature. This clearly reflects the inability of the formal sector to absorb an increasing number of job-seekers, thus resulting in a worrying problem of unemployment and, if individuals remain unemployed for prolonged periods without any gainful income, they may experience the hardships of poverty.
On an expanded basis, South Africa's current unemployment rate, which includes the discouraged work seekers, is close to 30 per cent, although the 'official' unemployment rate in third quarter of 2008 (SARB, 2009) is about 22 per cent, and increased to 24.5 per cent in the third quarter of 2009 (Stats SA). Discouraged work seekers increased from 1.07 million to 1.17 million during the fourth quarter in 2008 (SARB, 2009). This situation worsened as the domestic economy experienced a further contraction in formal employment levels (1.8 per cent in 2008/Q4 and 6.4 per cent in 2009/Q1), (SARB, June 2009). These performances in part result from the then current economic downturn and changes in the global economy.

The government put various structures and strategies in place to meet the challenge of job creation. These include (some of which are no longer in effect) the growth, employment and redistribution strategy (GEAR), Special Development Initiatives (SDI), the Umsombuvu Youth Agency, SMME development institutions, National Skills Fund, the Sector Education and Training Authorities (SETAs), National Empowerment Fund, 
Accelerated and Shared Growth Initiative of South Africa (ASGISA), and expanded cabinet responsibilities to deal with development and employment in June 2009. Despite all these initiatives, South Africa's contemporary growth and unemployment rates are a development concern, together with associated issues regarding aggregate demand, inflation, interest rates, budget deficits and increasing income inequalities. The prospects for sustained and rapid growth, without which poverty cannot be addressed, are themselves negatively affected by increasing inequality, poverty and unemployment (Bhorat \& Kanbur, 2005).

Increasingly there are signs of disillusionment among individuals, as unemployment among the poorer community remains extremely high. Crime rates are alarming, the HIV/AIDs pandemic is still at a high level, corruption is a major issue and service delivery remains a formidable challenge, while disgruntled workers in various sectors are increasingly expressing their disaffection with salary or working conditions.

After almost 15 years of post-apartheid democracy, many individuals are asking, "where are the promised jobs?" contributing to a "better life" for all in South Africa. Indeed, in his State of Nation address in May 2009, President Zuma raised hopes, highlighting the new government's commitment to, inter alia, reducing poverty and unemployment, promising the creation of 500,000 new jobs; apparently in the second half of this recessionary year (2009).

Against this background, this paper examines South Africa's problem of high unemployment despite economic growth. It consists of four sections. The first examines a simplified analysis of jobless growth highlighting the growth performance against a background of unemployment in recent years, the second discusses real GDP within the context of the Harrod-Domar model and presents a marginal employment effect regression analysis using data for the period 1994-2008 and even prior to 1994, the third examines the causes of poor employment in relation to growth performance, and the final section presents some alternative employment enhancing measures.

\section{2}

\section{Recent economic growth and unemployment rates in South Africa}

In 1993, the economy grew at a real rate of 1.2 per cent. For the next seven years (19942000 ) it grew at an average annual rate of 2.7 per cent (SARB, Dec 2001), (Table 1). Accordingly, real GDP per capita increased from R20 214 in 1994 to R21 104 in 2000 and to R25 897 in 2008 (SARB, March 2009), as the economy registered annual growth levels of up to 5 per cent and more as late as 2007 (Table 1). ${ }^{1}$

Table 1

South Africa's Real GDP 1994 - 2008

\begin{tabular}{|c|c|c|}
\hline Year & Real GDP & Real GDP per capita Rand \\
\hline 1994 & 3.2 & 20214 \\
\hline 1995 & 3.1 & 20412 \\
\hline 1996 & 4.3 & 20848 \\
\hline 1997 & 2.6 & 20955 \\
\hline 1998 & 0.5 & 20625 \\
\hline 1999 & 2.4 & 20675 \\
\hline 2000 & 4.2 & 21104 \\
\hline 2001 & 2.7 & 21269 \\
\hline 2002 & 3.7 & 21663 \\
\hline 2003 & 3.1 & 21991 \\
\hline 2004 & 4.9 & 22735 \\
\hline 2005 & 5.0 & 23540 \\
\hline 2006 & 5.3 & 24475 \\
\hline 2007 & 5.1 & 25514 \\
\hline 2008 & 3.1 & 25897 \\
\hline
\end{tabular}

Source: SARB Quarterly Bulletins 
The RDP office was abolished in 1995, and the new macroeconomic growth, employment and redistribution (GEAR) strategy was then implemented in 1996. This move recognizes that unless the economy grows robustly there can be neither substantial employment creation nor significant redistribution to the poor.

In terms of the GEAR strategy, South Africa expected to achieve an average annual growth rate of 6 per cent over the 1996-2000 period, and it was projected that some 400000 new jobs per annum were to be created. From a theoretical perspective, a strong association may well exist between growth and employment in a labour surplus economy. An accelerated economic growth underpinned by appropriate technology could significantly pull up labour employment, while enabling a rise in labour-intensive investment in some sectors further boosting employment. However, contrary to expectations, the country produced a striking case of jobless growth during certain years in the 1990s (Loots, 1998).

South Africa registered an average growth rate of 5 per cent during the period 2004-2007. More recently, economic growth responded positively to the stimulus from public sector infrastructure investment, especially in roads, stadia, the Gautrain project and improvements of airports in anticipation of the 2010 Soccer World Cup. As a result, expanded unemployment declined from 37 per cent in 2003 to 29 per cent in 2007 and it increased to 29.3 per cent in 2008. Economic growth was accompanied by an increase of 1.8 million jobs from 2004 to 2007, but employment growth was not high or stable. In effect, the labour force grew by over 5 million individuals, resulting in significant rise in unemployment levels to close to 8 million in 2002 (Bhorat \& Oosthuizen, 2006). The rate of total employment growth trended downwards from above 4 per cent in 2004 to under 1 per cent in 2007, relative to an upward-trending economic growth (du Toit \& van Tonder, 2009).
The long-term employment trend indicates that unemployment (expanded) rates increased from 6.7 per cent in 1960 to 10.6 per cent in 1983, to over 29 per cent in 2009, amid structural change, policy changes and increasing retrenchments in recent times. This implies that the job scarcity rate (percentage of workers without formal employment) increased from a mere 10 per cent in 1960 to approximately 47 per cent in 1995 (Loots, 1996) and close to 30 per cent in the post-2000 period. While the formal sector was able to absorb 80 per cent of the labour force before the 1980 s, this figure dropped to nearly 50 per cent after 2000 (Barker, 2006:45). ${ }^{2}$ More employment seems to have been created in the informal sector rather than in the formal sector, thus widening income inequality and the gap between the first and the second economy. The jobs created by the informal sector are of a low value-adding nature, while the formal sector makes the greater contribution to wealth creation and GDP. Indeed, South Africa's Gini coefficient, reflecting income inequality, has increased from 0.57 in 1992 to 0.70 in 2008 (du Toit \& van Tonder, 2009:15).

The relation of unemployment with GDP can be assessed more accurately when the change in GDP is linked to the change in employment, which is done in Table 2 below. This is an indication of the responsiveness of employment to changes in economic growth. The GDP-employment growth was consistently negative during the period 19952000, with an average figure of -1.4 (Mahadea, 2003), reflecting that South Africa's growth has not been neutral but rather labour displacing. Labour displacement relative to the country's GDP appears to have been at -1.6 in 2001, but thereafter labour absorption improved. The change in employment index ranged from 3.2 per cent (2008) to 19.4 per cent (2002), and the GDP-employment ratio has been positive, the highest in 2008, with a figure of 0.968 (Table 2). 
Table 2

Labour employment, capital labour ratio and GDP/employment ratio: 2000-2008

\begin{tabular}{|c|c|c|c|c|}
\hline Year & $\begin{array}{l}\text { Average capital } \\
\text { labour ratio in rand }\end{array}$ & $\begin{array}{l}\text { Labour } \\
\text { employment index }\end{array}$ & $\begin{array}{l}\text { Change } \\
\text { per cent }\end{array}$ & $\begin{array}{l}\text { Ratio of GDP growth }\left(g_{y}\right) \\
\text { to employment growth }\left(g_{1}\right)\end{array}$ \\
\hline 2000 & 124236 & 100 & - & - \\
\hline 2001 & 123024 & 98.4 & -1.6 & -1.68 \\
\hline 2002 & 121918 & 117.8 & 19.4 & 0.190 \\
\hline 2003 & 121436 & 135.1 & 17.3 & 0.179 \\
\hline 2004 & 121630 & 140.7 & 5.6 & 0.875 \\
\hline 2005 & 122556 & 150.2 & 9.5 & 0.526 \\
\hline 2006 & 124563 & 167.1 & 16.9 & 0.313 \\
\hline 2007 & 127912 & 175.8 & 8.7 & 0.586 \\
\hline 2008 & 132670 & 179 & 3.2 & 0.968 \\
\hline
\end{tabular}

Source: SARB Quarterly Bulletins

Output expansion with a less than proportionate increase in the labour force (in Table 2 note the years 2002 and 2006 for example) may reflect an increase in capital input and total factor productivity. The average capital-labour ratio increased from R124 236 in 2000 to R132 670 in 2008 (Table 2), reflecting a rising capital intensity in production. Accordingly, the average output labour ratio improved from R49 662 in 1994 to R63 437 (at constant 2000 prices) in 2008. However, the growth in output per worker in the formal non-agricultural sectors decreased from 6.3 per cent in 2000 to 0.8 per cent in the third quarter of 2008 (SARB, March 2009), and to -0.4 per cent in fourth quarter of 2008 (SARB, June 2009).

Except for the year 2008, the ratio of GDP growth to employment growth has been far less than one, reflecting that South Africa's job creation performance against GDP has been rather weak for most years of the period 20022008 with many of the unemployed ending up in the informal economy. During the years 2000-2005, on average 21 per cent of the employed were engaged in the impoverished informal sector (Burger and $\mathrm{Yu}, 2006$ ). This reinforces the point that the employment elasticity of economic growth is rather low in South Africa; also notice in Table 2 above, that more recently the ability of the economy to absorb labour is waning, as the growth in output has not really resulted in a matching growth in employment. If one chooses a ratio of one half as a benchmark (indicating a labour absorbing economy), it is to be noted that more recently (in 2008 and 2004) the economy has not been under this benchmark.

Figure 1

Simplified analysis of jobless growth

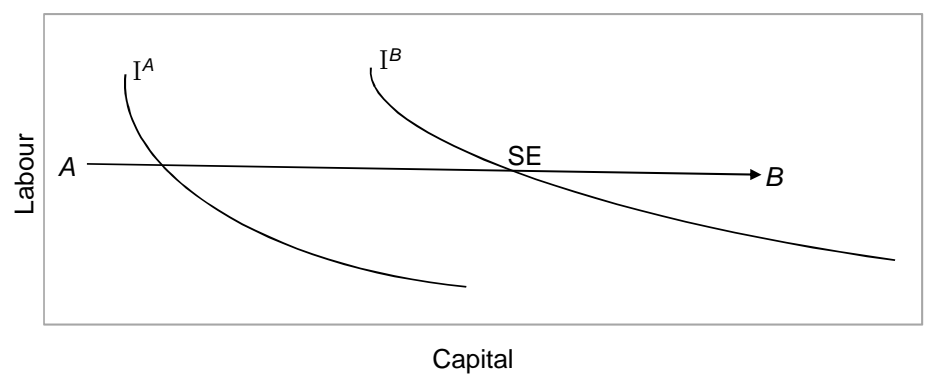

In Figure 1 is an analysis of jobless growth based on the growth and unemployment

figures for South Africa. Adopting a naive ${ }^{3}$ production function approach, we show two 
isoquants $\left(\mathrm{I}^{\mathrm{A}}\right.$ and $\left.\mathrm{I}^{\mathrm{B}}\right)$ with labour and capital as the inputs. Given that we are attempting to capture some aspects of the South African economy, it makes little sense to begin at the origin. The first isoquant, which is labeled $\mathrm{I}^{\mathrm{A}}$, also shows the initial equilibrium position at A, so as to avoid too many labels in the figure. The second isoquant has label $\mathrm{I}^{\mathrm{B}}$. One can consider a move from the isoquant $\mathrm{I}^{\mathrm{A}}$ to the isoquant $\mathrm{I}^{\mathrm{B}}$ as a way to capture, in a rather "heroic" manner, economic growth as there is more being produced in goods and services and Table 1 does measure real growth. As tables 1 and 3 show, South Africa certainly has posted good growth rates in the recent past. As point $\mathrm{A}$ (on $\mathrm{I}^{\mathrm{A}}$ ) is also the initial equilibrium, the arrow $A B$, shows the evolution of the economy towards $\mathrm{I}^{\mathrm{B}}$ (real growth) and the subsequent equilibrium is shown as point $\mathrm{SE}$ in Figure 1. Overstating the case somewhat, and in this very stylized view, that has some merit, we see that the labour to capital ratio has fallen (it is lower at SE and this is also evident in Table 2 above and supported by results in Table 4 below): one can then view the move from $A$ to SE, in labour units (measured on the vertical axis), as one way to conceive the idea of jobless growth.

\section{3}

\section{Harrod-Domar growth model, South Africa's real gdp and marginal employment effect}

In terms of neo-classical growth economics, population growth, capital accumulation and technological progress each contribute to the economic growth of nations (Solow, 1994). For much of the period 1950-2005 experts in international aid have been guided by the view that low growth and under-development are associated with insufficient savings and investment (the S-I gap) and foreign exchange limitations (the X-M gap), both gaps calling for net inflow of foreign capital (Sachs, 2005; Easterly, 1997). This "aid" guidance view is in tune with Keynes' theory of income determination, which emphasizes the role of investment in short-run economic growth (Bauer, 1972; Ingham, 1995). However, new growth or endogenous growth models emphasize entrepreneurial ideas, institutions, good governance and human capital as critical to economic growth (Lucas, 2009; Romer, 1994; Barro \& Sala-i-Martin, 1995; Rodrik, 2000 and Grindle, 2004). Older growth models, such as those of Smith and Schumpeter also stress the role of entrepreneurship.

Within the Keynesian framework, the simple Harrod-Domar model, $\mathrm{g}=\mathrm{s} / \mathrm{k}$ (where $\mathrm{g}$ is the economic growth rate; $\mathrm{s}$ is the average saving ratio and $\mathrm{k}$ is the incremental capital output ratio) can be useful as heuristic guide in analyzing the real economic growth of South Africa. As commentators from Bauer to Easterly have pointed out, the danger of the financing gap approach comes from using it as a measuring rod for large scale disbursements. Domar (1946) postulates that savings and the incremental capital output ratio provide the key to investment-led growth. Once the investment incremental capital-output ratio (ICOR) is known, the saving-income ratio necessary to generate a given rate of economic growth can be found.

Taking an optimistic view, South Africa needs a 6 per cent growth rate to create 400 000 jobs annually. With an ICOR of 6.1 (Table 3 , where we include some previous years for comparison), South Africa would have had to invest close to 37 (the six required divided by the 2.64 posted multiplied by 16) per cent of its GDP over the period 1996-2000 to attain a 6 per cent growth rate. Even if an optimistic investment-incremental ratio of 5 were assumed, then an additional investment of 30 per cent relative to GDP would be required to attain a real GDP growth rate of 6 per cent. Clearly this investment (30 per cent) as a proportion of GDP is well above the average 16 per cent actually registered for the period 1996-2000. However, investment as a proportion of GDP has increased from 15 per cent in 2000 to 23.2 per cent in 2008 (SARB, 2009). South Africa registered an average annual GDP growth of 4.1 per cent from 2001 to 2008. If we assume an ICOR of 4.5 , South Africa would need an investment of 27 per cent as a proportion of GDP to reach the 6 per cent growth target and make a dent in unemployment. The actual investment at 18.4 per cent of GDP is far from that target. 
Table 3

Investment and average real GDP in South Africa: 1986-2008.

\begin{tabular}{|c|c|c|c|}
\hline Year & $\begin{array}{c}\text { Investment as per cent } \\
\text { of GDP }\end{array}$ & Real GDP & ICOR \\
\hline $1986-95$ & 18.3 & 1.31 & 14.6 \\
\hline $1996-2000$ & 16 & 2.64 & 6.1 \\
\hline $2001-2008$ & 18.4 & 4.1 & 4.5 \\
\hline
\end{tabular}

Again more recently, we note that South Africa technically entered into a recession in 2009, after 17 years of continuous expansion, (real GDP contracting by 1.8 in the last quarter of 2008 and by 6.4 per cent in first quarter of 2009). Real gross capital formation slowed to 2.6 per cent in the first quarter of 2009 (SARB, June 2009). Investment, as an injection in the traditional Keynesian sense, should raise income, output and employment. In order to enhance investment and growth, it is necessary to have an improved saving record. However, gross saving as a ratio of GDP actually decreased from 16.9 in 1994 to 15.4 in 2008. At the household level, saving in relation to disposable income decreased from 2.8 per cent in 1994 to -0.4 per cent (borrowing) in 2008, clearly reflecting an increase in household debt. In effect, the ratio of household debt to disposable income increased from 55.5 in 1994 to 76.6 in 2008 (SARB, June 2009). However, there has been an improvement in the efficiency of investment between the period 1996-2000 and 2001-2008, as reflected by the reduced ICOR from 6.1 to 4.5 over the same period (Table 3 ).

Table 4

Non-spurious regression results linking endogenous real GDP growth (rgdpg) to the marginal employment effect (Mee) in South Africa: 1946-2008

\begin{tabular}{|c|c|c|c|c|}
\hline \multicolumn{5}{|c|}{ Statistics } \\
\hline Variable & Mean & Minimum & Maximum & Standard Deviation \\
\hline Rgdpg & \multirow{2}{*}{$\begin{array}{c}3.53607 \\
-0.0311475\end{array}$} & -2.2 & \multirow{2}{*}{$\begin{array}{l}5.6 \\
7.2\end{array}$} & 2.22755 \\
\hline Mee & & -6.9 & & 2.27384 \\
\hline \multicolumn{5}{|c|}{ Regression Results } \\
\hline \multicolumn{5}{|c|}{$\begin{array}{c}\text { Mee }=-0.5761+0.1541 \mathrm{Rgdpg} \\
t \text {-values }(-1.049)(1.1732) \\
\text { R-squared }=0.0228\end{array}$} \\
\hline \multicolumn{5}{|c|}{ Stationary Test } \\
\hline \multicolumn{2}{|c|}{ Variable } & \multicolumn{2}{|c|}{ Coefficient } & T-statistic \\
\hline \multicolumn{2}{|c|}{ Rgdpg } & \multicolumn{2}{|l|}{-0.4950} & -3.0246 \\
\hline \multicolumn{2}{|c|}{ Mee } & \multicolumn{2}{|l|}{-2.5659} & -7.7773 \\
\hline \multicolumn{5}{|c|}{$\begin{array}{l}\text { Critical Values for Stationary Test } \\
\text { Davidson, R. and MacKinnon, J. (1993), } \\
\text { "Estimation and Inference in Econometrics" page 708, Table 20.1, } \\
\text { Oxford University Press, London } \\
\begin{array}{lll}1 \% & 5 \% & 10 \% \\
-3.96 & -3.41 & -3.13\end{array}\end{array}$} \\
\hline
\end{tabular}

As any inference drawn from Table 2 is based on a limited number of observations, we feel that in order to substantiate the poor link between the real growth and a less than proportionate increase in employment, it is of some interest to examine this relationship for a longer time period. While the links between changes in unemployment and changes in output growth might be complex, one way of understanding the links is to use the ever 
popular regression method of least squares. Unemployment and growth are likely to be related; so regressing one on the other can be instructive, as one can perhaps ascertain in some crude way the size of the influence of economic growth on employment. Accordingly, the analysis that initially covered the period 1994-2008, is extended to the 1940s. Moreover, owing to extreme nonstationary results, a longer time period is deemed necessary. Thus, using South African data from 1946, on real GDP growth (Rgdpg in Table 4) and the change in employment growth, a marginal employment effect, (Mee in Table 4), we perform a rather 'crude' analysis of the link between these variables expressed in the regression model below, where $\mathrm{a}$ is constant and $\mathrm{b}$ is the regression coefficient of real GDP growth, and the dependent factor is the marginal employment effect (Mee).

Mee $=\mathrm{a}+\mathrm{b}$ Rgdpg

Many factors determine the employment growth rate in any one year, but what matters for a job-seeker in that year is not the growth rate per se but how the growth rate has changed from last year when s/he was unemployed, a marginal employment effect shown as the variable Mee in Table 4.

Both variables span a large number of years and the marginal employment effect is stationary. However, the GDP growth rate does not, strictly speaking, pass the stationary test, but it is not too far off. As Table 4 indicates the calculated value of the test statistic is -3.0246 , which should be smaller than -3.13 , but is clearly not a poor failure of the test. The poor (low $\mathrm{R}^{2}$ and insignificant $\mathrm{t}$ - values) results of the regression indicate an absence of spurious results. If real GDP growth is able to change the growth in employment directly from one year to the next in a marginal sense, then the estimated coefficient should be one. What is found, though not cast in stone, is instructive that the size impact of growth on marginal employment is positive and less than proportionate $^{4}$, as the statistically nonsignificant co-efficient of real GDP growth (Rgdpg) is 0.1541 (Table 4). Of additional interest is the measured intercept (capturing omitted $^{5}$ effects) that is much larger in absolute size (0.5761), but all these effects (which we identify here and in section 4 below) reduce additional employment growth. It would be instructive to be able to break the sample down further and determine whether this latter effect is getting stronger in the new millennium. However to do this one has to reduce the time span of the data. Using this data, a reduction in the sample size makes inference difficult, as the variables would no longer be stationary.

In considering macro unemployment, we are adding the various types of unemployment here. But let us argue that the real wage (w/p) in the cyclical labour market, as shown in Figure 2, is set by search and other structural behaviour.

Figure 2

Structural and cyclical effects on unemployment

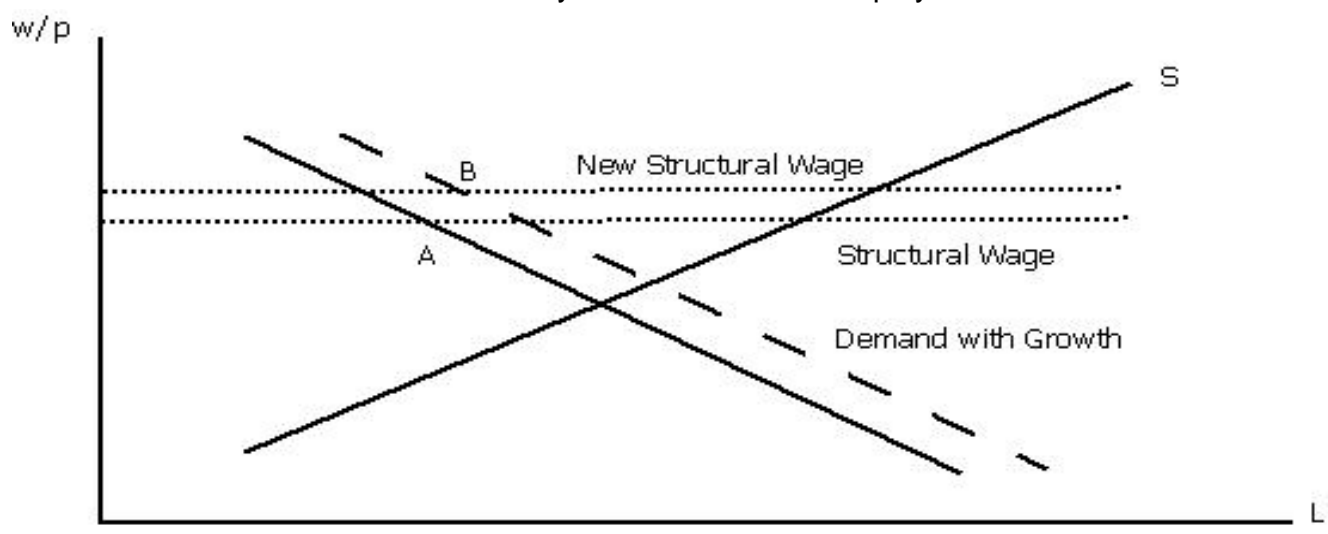


The economy begins at A and growth shifts the demand for labour and if the structural forces change at the same time, then the economy can end up at B with a less than proportionate increase in employment. This indirectly entails a rise in unemployment. This can take many forms: frictional (where people are changing jobs and unemployed for a short period between jobs), structural (where people are unemployed partly owing to a decline in certain industries and changes in the production process), seasonal (people who are unemployed during off-peak seasons), and cyclical (where individuals are unemployed as a result of a fall in the level of economic activity during a recession or depression). Economic growth absorbs some labour, but structural factors mitigate against complete labour absorption, with some workers engaging in a search process.

Although two different concepts of unemployment are used in South Africa, (the broad and narrow one), it is the broad measure of unemployment that provides a more accurate reflection of joblessness in the South African labour market (Kingdom \& Knight, 2005). The narrow definition assumes that the unemployed labour is discouraged and does not search for employment within a reference period and thus do not form part of the mass of unemployed. However, in reality both searching and non-searching unemployment has increased significantly since 1995 and "non-searchers are no less pained by their joblessness than the searchers", and they are not any happier than the searching unemployed (Kingdom \& Knight, 2005:10).

As the economy continues to display a lacklustre performance, unemployment continues to sweep across the provinces of the country, with some provinces harder hit than others. The pledges of "decent jobs" being created have become unrealised promises. It is important to understand what underpins this rising joblessness. This is covered in the next section.

\section{4 \\ Challenges of the increasing joblessness}

\subsection{Globalization and labour legislation}

The process of trade liberalisation in South Africa gained momentum in 1995. As tariffs have been lowered in accord with the country's commitments to GATT/WTO, manufactured exports as a proportion of GDP increased from 14 per cent in 1994 to 21 per cent in 2008. Further, as international sanctions were withdrawn, trade opportunities with the external world emerged. However, South Africa's integration with the global world impacted adversely on the country's labour market, as the resulting export growth did not strengthen the labour absorption capacity enough to significantly reduce unemployment. South African firms have had to rationalise and re-engineer activities to improve productivity to meet international competition, and this has been at the cost of low-skilled jobs (Edwards, 2001; Bhorat \& Hodge, 1999).

Export growth in South Africa is strongly linked to relative wages in export industries. But the long run employment-wage elasticity is found to be consistently negative, ranging from -0.5 to -0.7 (Fallon \& Lucas, 1998; Bhorat \& Leibbrant, 1998), suggesting that a 10 per cent increase in wages results in a decrease in employment of up to 7 per cent. According to Edwards and Swarthmore (2003), a one per cent decline in relative unit labour cost in South Africa results in a 2.6 per cent rise in exports to developed countries. In South Africa import penetration has been higher than export growth. Import penetration has adverse consequences for income and employment growth whereas exports have a positive effect. Rodrik (2006) argues that the weakness of the export-oriented manufacturing, in particular, has deprived the country from growth opportunities and job creation at the low end of the skill distribution. 
Employment growth is premised on; inter alia, robust growth of labour-intensive industrial sectors, exports, and institutional flexibility. But what we find in practice is that various new labour laws have imposed rigidities on the labor market, and many employers, burdened by a multitude of labour regulations, switch to capital-intensive methods. In the Classical model, labour market flexibility is critical for job creation and, as Barker (2006:54) argues, it is an important element in the battle against unemployment. In situations where wages are rigid, the impact of these regulatory 'shocks' show up in unemployment as firms are unable to adjust wages downward to meet competitive pressures. Thus, stringent labour legislation (the new Labour Relations Act, 1995, Basic Conditions of Employment Act, 1997 and Employment Equity Act, 1998) are depriving the labour market of much-needed flexibility for job expansion. The extension of minimum wages to many sectors may well have destroyed jobs in small labour-intensive firms (Nattrass, 1998).

This recent legislation has imposed a tremendous burden on the opportunity cost of management time, firms' total wage bills and real transaction costs of doing business in South Africa. These burdensome obligations on employers clearly make hiring and firing too prohibitive. South Africa has many lowskilled labour and low-skilled potential employers who do not have the capacity to administer or comply with the requirements of the labour laws, thus they have a retarding effect on creating low skilled employment. The current difficult labour legislation in South Africa, along with the rigidity of the employment index at 52 ( 0 is less rigid) makes it difficult for firms to hire and fire workers (World Bank, 2006). The resultant increase in labour market rigidity, the overbearing protection of employees against unfair discrimination and the increased cost of doing business not only add to the disincentive for firms to hire new labour but also add to the unemployed, as (small) firms are likely to respond by cutting employment to below the critical norm of 50 workers (Black \& Rankin, 1998). However, it is encouraging that the government has recently proposed to review certain 'unfriendly' aspects of legislation to encourage investment and job creation in the SMME sector.

\subsection{Structural change}

Between 2000 and 2008, labour productivity increased by a total of 33.7 per cent (SARB, 2009). However, this improvement was invariably achieved via a reduction in low skilled and low productivity jobs within each economic activity and the substitution of capital for labour. Rodrik (2006) identified three trends in the South African economy that contribute to dampen the demand for low skilled workers and to unemployment. These are:

- substitution towards skilled workers within each economic activity,

- structural change away from low-skill intensive parts of economy, especially from tradables to services;

- production techniques becoming progressively more capital intensive within the tradable or manufacturing sector.

Thus, South Africa is moving away from a labour-intensive output growth path, as partly reflected in falling share of manufacturing employment and contribution to GDP and rising employment and output in the services sector, especially in construction, trade and financial institutions. The contribution of agriculture to GDP decreased from 5 per cent in 1990 to 3 per cent in 2004, industry combined with manufacturing decreased from 64 per cent to 52 per cent and services increased from 55 per cent to 65 per cent during the same period (World Bank, 2006). Formal employment in manufacturing has declined from 1.6 million in 1990 to 1.2 in 2008; employment in agriculture declined from 1.2 million in 2000 to 871260 , and employment in mining declined from 521379 to 474007 over the same period, clearly indicating a structural change(Stats SA, 2008). The fall in semi-skilled and unskilled employment, from 1 million to 0.7 million accounts for the bulk of this decline (Rodrik, 2006).

More recently the manufacturing sector in South Africa declined by 21.6 per cent over the last two years (2007-2008), shedding almost 
80000 jobs, with job losses being more pronounced in the textile, clothing and leather sectors. In the last quarter of 2008, about 42400 jobs were lost in the private sector, of which 20700 jobs were in manufacturing, 4000 in mining and 11200 in the financial sector. Although the public sector created 27600 jobs, overall formal non-agricultural employment in a single quarter decreased by 14800 (SARB, June 2009). The contracting trend in the manufacturing and mining sectors, which contribute to about a fifth of the country's GDP, may continue in much of 2010 against a background of weak demand in the domestic and global economy.

While the labour market for skilled workers in South Africa operates in accordance with theory, the same does not hold for the unskilled segment (Fallon and Lucas, 1998), clearly reflecting the realities of a dual South African labour market. If real wages are permitted to fall, the unskilled labourers may price themselves into jobs. This may be a politically sensitive issue in view of rising poverty and the role of trade unions in the new democratic government. However, some 12 million households that receive generous grants from the government may view paid employment and social grants as substitutes at the margin. Thus, employment creation has been hampered by the structural changes and institutional realities of a segmented labour market.

\subsection{Crime and corruption}

Rising crime levels and corruption inhibit expansions of investment and employment (Schoeman \& Blignaut, 1998; World Bank, 2006). A conservative Nedcor survey indicates that crime is costing South African private businesses and households R31.3 billion in 1995 (Nedcor, 1996:9). The total cost, including public sector expenditures, of combating crime in South Africa is much higher now in South Africa with some 50 murders and 99 reported rapes everyday (The Economist, 4/7/09:38). The crime situation has branded the country as a high risk investment destination. A recent study commissioned by the Presidency confirms the adverse effects of crime: over half of South Africa's small businesses were victims of crime and about a quarter were reluctant to expand or employ more labour; at least a fifth of their annual turnover is lost to crime through direct and indirect costs (Benjamin, 2008). For every business that closes, because of crime, at least six jobs are lost (Geldenhuys, 2008).

While South Africa is failing to attract substantial labour-intensive FDI, it is also losing on human capital, as people with marketable and entrepreneurial ability to create jobs, are leaving for other destinations. Many young talented individuals are going overseas, as they perceive insecurity and poor employment prospects here, resulting from alarming crime rates and affirmative action practices. This brain drain acts as a brake on economic growth (Kausch \& Jovanovic, 2001; The Economist, 1/9/2001:38). And slow growth raises the fear of further increases in unemployment and poverty.

\subsection{HIV/Aids}

HIV prevalence has a significant negative effect on the growth rate of per capita GDP in Sub-Saharan Africa (Lovasz \& Schipp, 2009: 245). South Africa has one of the highest absolute number of HIV infections in the world (Thurlow, Gow \& George, 2009). UNAIDS estimate that some 5 million South Africans are HIV-positive (The Economist, 23/2/02:45); this means that one in nine South Africans or 20 per cent of the adult population is infected by the virus (The Economist, 24/2/01:8). According to Statistics SA, in 2009 the estimated number of people living with HIV is about 5.21 million and the number of new infections is 413000 (Natal Witness, 28/07/09). HIV/Aids is likely to reduce South Africa's GDP by 1.7 per cent in 2010 (The Economist, 24/2/01:9) and by 5.7 per cent in 2015, according the Stellenbosch Bureau for Economic Research (cited in the Sunday Tribune 14/4/02). As the disease intensifies, this would no doubt impose a drag on the country's manpower, profitability, total factor productivity and accumulation of knowledge or human capital, all necessary for generating growth.

HIV/Aids also hurts the uninfected individuals who remain behind as orphans, with their parents falling victims to Aids. The number of HIV-infected babies, who are likely 
to grow up as orphans in institutions, is another cost to society; 2 million such orphans are expected by 2010 (The Economist, 23/2/02: 45). Against this background of a high HIV labour force and burdensome labour legislation, machines and subcontractors are rapidly replacing permanent staff, while many firms are "casualing" their labour, finding that the only way to cope is by employing fewer people (The Economist, 10/2/01:75).

The above discussion clearly indicates that when viewed holistically, the combination of current economic downturn in the global economy, structural change in the country and current labour policies are not conducive to labour market flexibility, employment creation and economic growth. While South Africa's economy did not register a robust growth in 2009 with the global downturn, it is important to remember that a downturn does not last forever. Decision makers have to think entrepreneurially of how to adjust through a downturn, create jobs, and emerge stronger once the upturn commences. Policy-makers in both the private and public sectors must reposition themselves for the way forward.

\section{5}

\section{The way forward: economic prospects}

The growth of the South African economy is tied to the global economy. Signs of economic revival from the recession in the US, European and Asian economies - South Africa's major trading partners- would be beneficial for an upturn in the South African economy, in turn generating multiplier effects on income, output and employment. Indeed, research by the Harvard Group (2008) suggests that there is potential for formal employment to increase by about 50 per cent with suitable changes in labour policies. The hosting of the soccer World Cup in 2010 would no doubt generate further trickle-down and employment effects on the economy; as many as 500000 jobs are likely to created by the next year's world cup (The Economist, 4/7/09), to complement the trade benefits, particularly in tourism and the services sectors. Kingdom and Knight (2007) argue that it is crucial for South Africa to pursue a set of policies that promote economic growth, that promote employment and that labour market regulations require reconsideration, affording greater weight to the concerns of entrepreneurs and investors and to the interests of the unemployed and informally employed poor.

\subsection{Entrepreneurship}

Businesses are vital to economy recovery. A long-term solution to South Africa's unemployment and growth problem lies in the consolidation of existing entrepreneurship and in the stimulation of a new entrepreneurial class based on SMMEs, including the informal sector. It is only through the vigorous exercise of SMME entrepreneurship, underpinned by millions of viable and lasting enterprises that we can create millions of sustainable jobs and economic growth. Schlemmer and Levitz (1998:80-81) argue that the "optimal route" to employment is through the critical mass of informal sector and small businesses with active private-public support. In implementing the ASGISA policy, the government is adopting a big push approach to promoting entrepreneurship, particularly with regard to building up small businesses to bridge the gap between formal and informal economies.

Government support programs that encourage almost anyone to start a business may not be appropriate as these entice more people with low skills to start new firms disproportionately in competitive industries with low entry barriers. Many of these are likely to fail. However, failures can be a learning experience that prepares individuals through the downturn to be successful in their future business endeavours.

Firms operate in a real and competitive business environment. Despite many policy pronouncements, doing business in South Africa is not getting easier. South Africa's rank in the World Bank's Doing Business Report dropped from the $29^{\text {th }}$ position in 2007 to $34^{\text {th }}$ in 2009 (World Bank, 2009). A macroeconomic environment that is generally friendly to labour intensive investment would generate spillover growth effects, as firms and entrepreneurs are more likely to invest productively, create jobs, and contribute to output and poverty reduction. The current 
government's thinking about a developmental state that that will use state interventionist measures through procurement, market access, training, licensing and financial support to assist small and medium enterprises, as well as a wage subsidy for hiring young or inexperienced labour and reduced regulations for small business are very encouraging to entrepreneurship, is a step in the right direction.

However, the intangibles are equally important for entrepreneurship and job creation: these hinge on strengthening law and order, enforcing property rights, improving the governance of institutions and service delivery, and introducing greater market flexibility to make investment labour-friendly. Labour legislation in South Africa set against a background of an abundant pool of unskilled labour, is considered by some investors to be troublesome and prohibitive. It is imperative that unemployed individuals have the opportunity to accept low wage employment should they desire it. South Africa needs to take on the "foxy" route to succeed economically and achieve a sustained growth, through which jobs can be created (Illbury \& Sunter, 2007; Parsons, 2009:194-195). This entails, inter alia:

- Improving the educational and training capabilities of actual and potential South African labour, including entrepreneurs, and maintaining a high standard of education in learning institutions, compatible with market and entrepreneurial orientations in a more rapidly knowledgebased and transforming environment;

- A strong work ethic, resting on a sound family system, a strong non-intrusive competition-enhancing government, with minimum regulations, low taxation and corruption removal;

- A dual-logic economy, generating positive synergies between the large or mediumsized firms across all sectors, and the small and informal sector ventures;

- Encouraging savings through tax concessions;

- Mobilising capital to meet the needs of investors and 'foxy' entrepreneurs (Investment);
- Better labour-business relationships, and a good governance delivery state (Parsons, 2009).

To some extent, these measures are already in place, but much more can be done.

\subsection{Public works programmes}

Many countries have responded to the employment and growth crisis through government activism of a Keynesian type in the form of a short term public work's expansion programmes. These programmes can create indirect employment in other sectors, more so as the government is committed to maintaining the R787 billion infrastructure programme over next three years. If created in poor rural areas having high unemployment, public works infrastructure harbours the potential to provide the previously disadvantaged communities with wealth creation, earnings and learning opportunities. These should also help in alleviating poverty and migration, making rural life less of a burden.

It is, however, important to note that public works programmes are not without problems. They are not sustainable in the long run. As the new minister of finance, Praveen Gordhan, states that South Africa needs to look beyond the short term. The public works programmes need to be financed by government expenditure and this entails a drain on the fiscus, a reduction of state expenditure in other areas, or a rise in taxation with resultant crowding-out, debt servicing and other attendant disincentive effects, all of which involve negative implications for job creation and growth. Surely any further tax hikes that discourage risk taking from the entrepreneurial group, or reduce average household disposable income, would impact negatively on production and employment, let alone redistribution efforts.

\subsection{The very short term: A greater role for state intervention}

To cushion themselves against the effects of the recession, countries from the US to China have responded to save jobs and ensure firms' survival through state intervention. These countries have come up with stimulatory packages, as high as $\$ 450$ billion in China and 
a $\$ 900$ billion recovery plan in the US. South Africa too can rescue jobs in the immediate term by greater state involvement that complements its public work programmes through fiscal assistance to distressed firms.

It is encouraging to note that the Industrial Development Corporation (IDC) provided R500 million to 14 companies in distress in 2009 and has set aside R6.1 billion for more rescues in the next two years. Some form of greater protectionism for labour-intensive manufacturing firms against "cheap" imports, particularly in textiles and clothing may be desirable so as to help local companies retain jobs and remain solvent through the global downturn.

While extending the role of the state in the very short term as a response to job creation or the recession may be desirable, one questions the effectiveness of a bigger government that crowds out the private wealth creating sector amid a climate of slowing economic activity. Already, the government is experiencing a shortfall in tax revenue collection compared to the budget estimate. This budget deficit is likely to increase from R94 billion (February 2009, estimate) to R154 billion in 2010 (Sunday Times, 5/7/09). This represents 6 per cent of the country's GDP.

Additionally, the current account deficit on the South Africa's balance of payments is about 4 per cent relative to GDP (SARB, 2009). A recession could swell both deficits further as the government pledges to offer more socio-economic services to the poor, increase social grants to the unemployed, and assist companies that are in distress. High budget deficits are inflationary, with adverse implications for liquidity, debt servicing costs, interest rates and intergenerational debt burdens. These impose heavy costs on the present generation and even more on future generations.

\section{6}

\section{Conclusion}

Tackling South Africa's dilemma of low economic growth and worsening unemployment is a formidable challenge. The Harrod-Domar model points to insufficient investment as a constraint. However, there is no "quick fix" solution to this cycle of sluggish growth and high levels of joblessness in the current global economic climate. It is critical to establish a sound environment conducive to labour absorption development and business entrepreneurship. There may be some cautious optimism as the government pins its hopes on the 2010 World Cup and enlightened leadership of a development oriented state framework. Whether these are likely to generate massive job creation after 2010 is uncertain. But what is certain is that legislation does not create employment. The higher the degree of regulation in a country, the higher its unemployment rate tends to be. Greater flexibility in the labour market is a minimum requirement for employment creation.

It is entrepreneurial action that gives rise to growth and employment. In contrast, any economy can destroy jobs through high levels of crime, corruption, poor governance, excessive regulations and poor service delivery. The fires of entrepreneurship are best stoked in an investment-friendly and crimefree environment, where encouragement for entrepreneurs comes from a respect for property rights, high levels of saving and investment, improving education and training, and steady gains in productivity as well as equality of opportunity. Public works programmes and fiscal intervention may help in the short term. These, alone, are not a panacea. We cannot afford excessive government spending or deficits for long. As President Zuma emphasised in his 2009 State of the Nation address, we have "to minimise the impact on those most vulnerable... cut our cloth according to one's size", and "every cent must be spent wisely." Without the dynamism of entrepreneurs, the growing number of jobless will have little hope. Unless a propitious environment is created, the entrepreneurial and labour class will be incapable of realising its potential as a major engine for job creation, and catalyst for economic growth. As Kingdom and Knight (2007) succinctly stated, the problem of low employment growth in South Africa can only be solved through a policy environment that encourages growth with labour absorption, taking into consideration the needs of the unemployed. 


\section{Acknowledgement}

The authors would like to express their thanks to Professor S. Koch and two referees for their helpful comments and assistance on this paper.

\section{Endnotes}

1 While a real rate is not the same as an average annual rate, we use these concepts to describe the data in the table.

2 In sections 3 and 4 below, we attempt to provide some explanation for these shifts in employment.

3 Although this is a simplified model it does have a firm theoretical underpinning. Assume (and maximise) a standard CobbDouglas production function with capital and labour of the form $\sqrt{k} \sqrt{l}$, subject to the constraint $1 k+1 l=1$. Maximum output is at $\frac{1}{2}$. Raising the wage to 2 and allowing growth implies a new constraint $1 k+2 l=1.5$. It is easy to show that maximum output rises to 0.53033 and the capital and labour inputs rise from both being $\frac{1}{2}$ initially to 0.75 and 0.375 respectively as the above figure shows.

4 We begin with the excess supply (ES) of labour

$(a+b S)-(c-d D)-\mathrm{ES}=0$,

and have the imposed wage lie above the market clearing wage with linear schedules. The effect of a shift in labour demand is to reduce unemployment

$\partial_{c}(a-c+d D+b S)=-1$.

We then make the quantity of labour (both demanded or supplied) a function of the wage, $\frac{w}{p}$, and note that the effect of changing the wage raises the excess supply

$\partial \frac{w}{p}\left(a-c+b \frac{w}{p}+d \frac{w}{p}\right)=b+d$.

This means that a less than proportionate effect from growth is possible provided $b+d>-1$, which is not an unreasonable assumption in the labour market. This analysis allows a link between growth in output and growth in employment. The effect of growth in output $\left(\partial_{c}(a-c+d D+b S)\right)$ is to reduce the ES of labour directly as the effect is unity. However if at the same time there is any impediment in the labour market to raise the wage above market clearing levels for structural or search reasons the excess supply of labour increases which can offset the just identified reduction in the ES of labour. This offsetting effect means that as the economy grows, coupled with any stickiness in the real wage, the effect of that growth is to raise the growth of employment (a fall in the ES of labour) but not completely absorb all the ES of labour. This lead to an equation that can be subjected to an empirical test as follows: $0<\beta_{1}<1$

Mee $=\beta_{0}+\tilde{\beta}_{1} \operatorname{Rgdpg}$

Where $\beta_{0}$ captures all the omitted effects (which we admit are many) and the above analysis leads to the expectation that $0<\beta_{1}<1$ when the growth in employment (Mee for marginal employment effect) is related to growth in real GDP.

5 We recognise that the number of omitted effects here is huge. We would like to thank a reviewer for pointing out that these include the business cycle and wealth effects.

\section{References}

BARKER, F. 2006. The South African labour market: Critical issues for renaissance, J.L. van Schaik Publishers, Pretoria.

BARRO, R.J. \& SA-I-MARTIN, X. 1995. Economic growth, New York: McGraw-Hill.

BAUER, P. T. 1972. Dissent on Development, Cambridge: Harvard University Press.

BENJAMIN, C. 2008. South Africa: Crime crippling small business, Business Day, 17 July 2008.

BHORAT, H. \& KANBUR, R. 2005. Poverty and well-being in post-apartheid South Africa, Development Policy Research Unit Working Paper 05/101, UCT, Cape Town.

BHORAT, H. \& LEIBBRANT, M. 1998. Estimates of wage-emploment elasticities for South Africa, Unpublished.

BHORAT, H. \& OOSTHUIZEN, M. 2006. Evolution of the labour market: 1995-2002, in H. BHORAT \& R. KANBUR, 2006. Poverty and policy in post-apartheid South Africa, HSRC Press, Pretoria.

BHORAT, H. 2001. Labour market challenges in the post-apartheid South Africa: A country profile. Development Policy Research Unit, UCT.

BHORAT, H. \& HODGE, J. 1999. Decomposing shifts in labour demand in South Africa, South African Journal of Economics, 67(3):348-380.

BLACK, P. \& RANKIN, N. 1998. On the cost-increasing effects of new labour laws in South Africa, South African Journal of Economics, 66(4):452-463.

BOYLE, B. 2009. Ballooning budget gap, Sunday Times 5/7/09. 
BURGER, R. \& YU, D. 2006. Wage trends in post-apartheid South Africa: Constructing an earnings series from household survey data, Labour Market Frontiers, October:1-8

CHENERY, H. 1975. The Structuralist Approach to Development Policy, American Economic Review, 65(2). DOMAR, E. D. 1946. Capital Expansion, Rate of Growth and Employment, Econometrica, 14:137-47. DU TOIT, C. \& VAN TONDER, J. 2009. South Africa's economic performance: can we do better? In, Zumanomics, R. Parsons, (ed.) Auckland Park: Jacana.

EASTERLY, W. 1997. The ghost of financing gap: How the Harrod Domar growth model still haunts. Development Economics, (mimeo) World Bank Working Paper (July).

EDWARDS, L. 2001. Globalization and the skills bias of occupational employment in South Africa, South African Journal of Economics, 68(1):40-71.

FALLON, P. \& LUCAS, R. 1998. South African labour markets: Adjustment and inequalities. Washington, World Bank.

GELDENHUYS, H. 2008. Armed attacks in the rest of the country as crime spreads beyond Gauteng, Sunday Times 13/1/08.

GRINDLE, M. 2004. Good enough governance: Poverty reduction and reform in developing countries, Governance, 17(October).

HARVARD GROUP. 2008. Final recommendations of the international panel on growth, accessed at www.treasury.gov.za.

ILLBURY C. \& SUNTER, C. 2007. Socrates and the FOX: A strategic dialogue, Cape Town: Human Rousseau and Tafelburg.

INGHAM, B. 1995. Economics and Development, London: McGraw-Hill.

KAUSCH, B. AND JOVANOVIC, R. 2001. Brain drain is bane in the new economy, IT Web, March:34-38. KINGDOM, G. \& KNIGHT, J. 2005: Unemployment in South Africa, 1995-2003: Causes, problems and policies, Retrieved from http://www.csae.ox.ac.uk/.

KINGDOM, G. \& KNIGHT, J. 2007. Unemployment in South Africa, 1995-2003: Causes, problems and policies, Journal of African Economies, August.

LOOTS, E. 1998. Job creation and economic growth. South African Journal of Economics, 66(3):319-336.

LOVASZ, E. \& SCHIPP, B. 2009. The impact of HIV/AIDS on economic growth in Sub-Saharan Africa, South African Journal of Economics, 77(2):245-256.

LUCAS, R. E. 2009. Ideas and growth, Economica, 76(1):1-19.

MAHADEA, D. 2003. Employment and growth in South Africa: Hope or despair? South Africa Journal of Economics, 71(1):21-48.

NATTRASS, N. 1998. Growth, employment and economic policy in South Africa: A critical review. Centre for development and enterprise, Johannesburg.

NEDCOR 1996. The Nedcor project on crime, violence and investment: Main Report. Johannesburg. PARSONS, R. 2009. Zumanomics: Which Way to Shared Prosperity in South Africa?, Jacana, Sunnyside.

RODRIK, D. 2006. Understanding South Africa's economic puzzles, Centre for International Development Working Paper, Harvard University, August.

RODRIK, D. 2000. Institutions for high-quality growth: What they are and how to acquire them. National Bureau for Economic Research, Cambridge, U.K.

ROMER, P.M. 1994. The origins of endogenous growth, Journal of Economic Perspectives, 98(1):3-22.

SACHS, J. 2006. The End of Poverty, Penguin London.

SARB 2009. The South African Reserve Bank Quarterly Bulletins, Pretoria, No. 251-252 (March/June).

SARB 2008. The South African Reserve Bank Quarterly Bulletin, Pretoria, No. 248-250 (December).

SCHLEMMER, L. \& LEVITZ, C. 1998. Unemployment in South Africa: The facts, the prospects, and an explanation of solutions. South African Institute of Race Relations. Johannesburg.

SCHOEMAN, N.J. \& BLIGNAUT, J.N. 1998. Socioeconomic environment and labour absorption in South Africa, South African Journal of Economics, 63(3):299-318.

SOLOW, R.M. 1994. Perspectives on growth theory, Journal of Economic Perspectives, 8(1):45-54.

SOLOW, R.M. 1956. A contribution to the theory of economic growth, Quarterly Journal of Economics, (February):65-94. 
STATS SA 2008. Quarterly employment statistics, June 2008. Statistics South Africa, Pretoria. SUNDAY TIMES 2002. Jet-set president should take stock, 28/7/02.

SUNDAY TIMES 2002. Cabinet puts poverty grant on ice, 28/7/02.

SUNDAY TRIBUNE 2002. Aid deaths burst the beer sales bubble, 14/4/02:5.

THE ECONOMIST 2009. On the goal for 2010. 4/7/09:38.

THE ECONOMIST 2002. Stop denying the killer bug, 23/2/2002:45-46.

THE ECONOMIST 2001. Business and AIDS: The worst way to lose talent. 10/2/01:75.

THE ECONOMIST 2001. South Africa survey, 24/2/01.

THE WITNESS 2009. Statistics: SA population edges towards 50 million, 27/07/09.

THURLOW, J., GOW, J. \& GEORGE, G. 2009. HIV/AIDS, growth and poverty in Kwazulu-Natal and South Africa, Journal of International Aids Society, 12:12.

WHITESIDE, A. \& SUNTER, C. 2000. AIDS: The challenge for South Africa. Cape Town: Tafelberg. WORLD BANK 2006. World Bank Indicators, Washington D.C.

WORLD BANK 2009. Doing business 2010: Reforming through difficult times, Washington D.C. 